\title{
The Chemical Fermentation Process Properties, Bioactive Compounds, and Health Benefits of Fruit Vinegars in Pilot-Scale in Thailand
}

\section{Wilawan BOONSUPA}

Department of Biology, Faculty of Science and Technology, Rajabhat Maha Sarakham University, Mahasarakham 44000, Thailand

(Corresponding author's e-mail: wilawanboonsupa@ymail.com)

Received: 28 May 2020, Revised: 12 November 2020, Accepted: 28 December 2020

\begin{abstract}
Vinegar is a liquid product produced from alcoholic and acetous fermentation. Vinegar contains acetic acid and bioactive compounds, which are brewed by liquid-state and solid-state fermentation techniques. This study reviews chemical fermentation process properties, bioactive compounds, and health benefits of fruit vinegars in Thailand. Chemical properties are the alcohol percentage and acetic acid percentage of vinegar. Bioactive compounds include antioxidant activity and total phenolic content, which have the role of antioxidative activity, blood pressure and glucose control, and anti-tumor. However, further studies are needed to find the new fruit raw materials to produce fruit vinegar which have more bioactive compound and more good taste.
\end{abstract}

Keywords: Acetobacter pasteurianus, Antioxidant activity, Fermentation, Fruit vinegar, Wine

\section{Introduction}

Nowadays, pollution possesses a high risk in human life. It can be the cause of many diseases, including cancer and hypertension. Therefore, functional food is commonly produced to prevent such diseases. The production of vinegar is generally low in costs because sheap raw materials, like byproducts from local fruits and fruit waste, are utilized [1]. Vinegar is rich in nutrients including amino acids, vitamins, sugar, organic acids, polyphenols tetramethylpyrazine, and melanoidins [2]. Recently, the demand for fruit vinegars has increased because it benefits as health food products, which are used to promote different kinds of beneficial effects to humans, such as having antibacterial, antidiabetic effects and lowering cholesterol levels by inhibiting oxidation of low-density lipoproteins (LDLs). Thailand is considered one of the most abundant resources of tropical fruits in the world. The main fruit season in Thailand runs from April to July. There are many fruits in Thailand, e.g., mango, pummelo, and pineapple. The diversity of raw materials to produce vinegar is appealing because of the different nutrients, bioactive compounds, and cultivars. In China, the term vinegar is used to indicate both fermented and artificial vinegar, according to the Chinese National Standard definitions which classified vinegar in 3 grades, depending on the concentration of acetic acid (3.5 - 4.5, $4.5-6.0$, and $>6.0 \%)$ [1]

Vinegar production

Vinegar is produced from fruits containing sugar by a two-step fermentation, which consists of an alcoholic and acidic fermentation process. The first step is alcoholic fermentation during which hydrolyzed sugar is converted to ethanol and $\mathrm{CO}_{2}$ under anaerobic conditions by yeasts. The second step is acetic acid fermentation, in which the alcohol content in the first step is converted to acetic acid and water under aerobic conditions by acetic acid bacteria [3]. Vinegar content varies depending on factors, such as the raw material type and the production method [4]. There have been some studies conducted on 
the functional and chemical properties and possible use of tamarind, cantaloupe, mango, berry, pineapple, banana, and pumelo [5-12].

\section{Varieties of vinegar}

Vinegar is produced from sources that contain sugar such as fruits, grains, and honey. Different raw materials contribute to the different physiochemical properties of vinegar products. According to [1], vinegar varieties vary from country to country, some of the vinegars around the world are shown below (Table 1).

Table 1 Type of vinegar around the world.

\begin{tabular}{llll}
\hline Category & Raw material & Vinegar name & Geographical distribution \\
\hline Vegetable & Rice & Komesu, Kurosu, Heicu & East and Southeast Asia \\
& Malt & Malt vinegar & Northern Europe, USA \\
& Barley & Beer vinegar & Germany, Austria, Netherlands \\
& Wheat & Black vinegar & China, East Asia \\
& Sorghum & Black vinegar & China, East Asia \\
& Tea and sugar & Kombucha vinegar & Russia, China, Japan, Indonesia \\
& Sugarcane & Cane vinegar & France, USA \\
\hline Fruit & Apple & Cider vinegar & USA, Canada \\
& Grape & & \\
& Cooked must & Balsamic vinegar & Italy \\
& Red or white wine & Wine vinegar & Widespread \\
& Mango & Mango vinegar & East and Southeast Asia \\
& Mulberry & Mulberry vinegar & East and Southeast Asia \\
& Banana & Banana vinegar & Southeast Asia \\
& Coconut & Coconut water vinegar & Philippines, Sri Lanka \\
& Plum & Ume-su & Japan \\
& Kaki & Persimmon vinegar & South Korea \\
\hline Animal & Whey & Whey vinegar & Europe \\
& Honey & Honey vinegar & Europe, America, Africa \\
\hline
\end{tabular}

\section{Microorganism for vinegar production}

There are 2 fermentation processes to produce vinegar, which are alcoholic and acetous fermentation. Alcoholic fermentation usually depletes most sugars within the first weeks. Sugars are converted into ethanol by the action of yeasts (Saccharomyces cerevisiae) under anaerobic conditions, while in acetous fermentation, the acetic acid bacteria are the genus Acetobacter and can oxidize ethanol into acetic acid under aerobic conditions.

Yeast is a fungus in a vegetative state that is predominantly reproduced by budding or fission which results in growth that comprises mainly single cells. Yeasts are organisms with a respiratory metabolism that can grow in the presence of oxygen. Many types of yeasts in the absence of oxygen show a fermentative metabolism when metabolizing monosaccharides with 6 atoms of carbon like glucose, fructose, and mannose that were metabolized into 2 molecules of pyruvate in the glycolysis, called glycolysis pathway (Embden-Meyerhof glycolytic pathway. The pyruvate was reduced to ethanol $\left(\mathrm{C}_{2} \mathrm{H}_{5} \mathrm{OH}\right)$ and carbon dioxide by the enzyme pyruvate decarboxylase and alcohol dehydrogenase [13]. The overall chemical reaction is presented as:

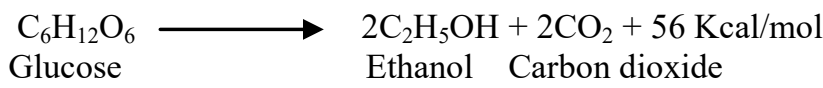


Table 2 shows the most important minor products of fermentation produced by Saccharomyces cerevisiae [1].

Table 2 Minor products of alcoholic fermentation produced by Saccharomyces cerevisiae, about 100 vol of ethanol produced.

\begin{tabular}{lll}
\hline Compound & Amount & Origin \\
\hline Glycerol & $4-7 \mathrm{~g}$ & Sugar \\
Succinic acid & $0.30-0.6 \mathrm{~g}$ & Sugar \\
Acetic acid & $0.1-1 \mathrm{~g}$ & Sugar \\
Isoamylic alcohol & $100-300 \mathrm{mg}$ & Sugar and amino acid \\
Phenylethyl alcohol & $10-100 \mathrm{mg}$ & Sugar and amino acid \\
\hline
\end{tabular}

Acetic Acid Bacteria (AAB) are Gram-negative with ellipsoidal to rod-shaped morphologies, being motile due to the presence of flagella. AAB are mesophilic obligate aerobes that can oxidize sugar, sugar alcohol, and ethanol to allow the production of acetic acid. AAB are used as the starter cultures for vinegar production such as Acetobacter pasteurianus and A. polyoxogenes. In acetous fermentation, the biochemical mechanism for the conversion of alcohol into acetic acid start with the oxidation of alcohol into acetaldehyde in the presence of alcohol dehydrogenase. These dehydrogenase enzymes consist of quinoproteins and flavoproteins, which have pyrroloquinoline quinone and covalently linked flavin adenine dinucleotide as prosthetic groups, respectively. This membrane-bound ADH has pyrroloquinoline as a cofactor and is independent of $\mathrm{NAD}(\mathrm{P})+$, although a cytoplasmic $\mathrm{NAD}(\mathrm{P})+$-dependent alcohol dehydrogenase has also been identified. The latter, however, has a much lower specific activity than the membrane-bound $\mathrm{ADH}$ and a higher optimal $\mathrm{pH}$ of 6 to 8 , which limits its contribution to the oxidation process of ethanol. The ALDH is also located in the cytoplasmic membrane, which is independent of $\mathrm{NAD}(\mathrm{P})+$ and has an optimum $\mathrm{pH}$ of between 4 and 5 . It is, also, to catalyze the oxidation of acetaldehyde to acetate at lower $\mathrm{pH}$ values. Acetobacter strains can further oxidize acetic acid to $\mathrm{CO}_{2}$ and water through the tricarboxylic acid cycle, called over oxidation [11]. This occurs in the case of ethanol depletion, and seems to be an irreversible change in their metabolism [14]. The overall chemical reaction is presented as:

$$
\mathrm{CH}_{3} \mathrm{CH}_{2} \mathrm{OH} \stackrel{\mathrm{ADH}}{\longrightarrow} \mathrm{CH}_{3} \mathrm{CHO}+2 \mathrm{H} \stackrel{\mathrm{ALDH}}{\longrightarrow} \mathrm{CH}_{3} \mathrm{COOH}+2 \mathrm{H}
$$

The first reaction is catalyzed by alcohol dehydrogenase (ADH) and the second by aldehyde dehydrogenase $(\mathrm{ALDH})$, which is located at the outer surface of the cytoplasmic membrane.

\section{Raw Material for fruit vinegar production and their phytochemicals}

Thailand is located in the tropical zones and its climate is suitable for growing fruit, so a wide variety of fruits are available in all seasons; therefore, Thailand has a numerous of fruits which could produce vinegar, e.g., Tamarind, Cantaloupe, Mango, Mulberry, Pineapple, Banana, and Pomelo. Many fruit species can be used for vinegar production since they have 2 basic attributes (1) to be safe for human consumption (2) to be a direct or indirect source of fermentable sugars.

\section{Tamarind (Tamarindus indica)}

The dried tamarind pulp of commerce contains 8 - $18 \%$ tartaric acid (2, 3-dihydroxy butanedioic acid- $\mathrm{C}_{4} \mathrm{H}_{6} \mathrm{O}_{6}$, a dihydroxy carboxylic acid) and $25-45 \%$ reducing sugars, of which $70 \%$ is glucose and $30 \%$ fructose. Tamarind pulp is rich in minerals such as potassium (62 - 570 mg/100 g), phosphorus (86 - 
$190 \mathrm{mg} / 100 \mathrm{~g})$, and calcium $(81-466 \mathrm{mg} / 100 \mathrm{~g})$, and iron $(1.3-10.9 \mathrm{mg} / 100 \mathrm{~g})$ magnesium content is high $(25.6-30.2 \mathrm{mg} / 100 \mathrm{~g})$, as is sodium $(23.8-28.9 \mathrm{mg} / 100 \mathrm{~g})$, whereas copper $(0.8-1.2 \mathrm{mg} / 100 \mathrm{~g})$ and zinc $(0.8-0.9 \mathrm{mg} / 100 \mathrm{~g})$ are low. It also excels in riboflavin and is a good source of thiamin and niacin, but is poor in vitamin $\mathrm{A}$ and vitamin $\mathrm{C}$ [15].

\section{Cantaloupe (Cucumis melo)}

Cantaloupes are a low-calorie and low sodium refreshing fruit, enjoyed by people of all ages. Cantaloupe is high in potassium $(267 \mathrm{mg} / 100 \mathrm{~g})$, beta-carotenes $(2.02 \mathrm{mg} / 100 \mathrm{~g})$, vitamin A content $(3,382$ $\mathrm{IU} / 100 \mathrm{~g})$, vitamin $\mathrm{C}$ content $(36.7 \mathrm{mg} / 100 \mathrm{~g})$, vitamin $\mathrm{K}$ content $(2.5 \mu \mathrm{g} / 100 \mathrm{~g})$ and sugar content $(7.86$ $\mathrm{g} / 100 \mathrm{~g})[16]$.

\section{Mango (Mangifera indica L.)}

Mango is rich in bioactive compounds, such as proteins $(0.36-0.40 \mathrm{~g} / 100 \mathrm{~g}$ fresh weight $)$ of pulp, vitamin A (0.135 - $1.872 \mathrm{mg} / 100 \mathrm{~g}$ fresh weight pulp), vitamin C $(7.8-172 \mathrm{mg} / 100 \mathrm{~g}$ fresh weight of pulp), carotenoids $(0.78-29.34 \mu \mathrm{g} / \mathrm{g}$ fresh weight of pulp), phenolic compounds, dietary fiber (DF), carbohydrates, minerals, and other antioxidants [17].

\section{Mulberry (Morus indica)}

Mulberry is popularly consumed in the human diet in fresh and processed various forms, such as beverages, yogurts, and jams. The major groups of phenolic compounds present in berries are anthocyanins and phenolic acid. Mulberry contains cyaniding-3-glucoside and cyaniding-3-rutinoside [18].

\section{Pineapple (Ananas cosmosus)}

Pineapple contains a considerable amount of calcium, potassium, vitamin $\mathrm{C}$, carbohydrates, crude fiber, water, and different minerals that is good for the digestive system and helps in maintaining ideal weight and balanced nutrition. It contains $10-25 \mathrm{mg}$ of the vitamin. Pineapple juice contains ascorbic acid and is a good source of Vitamin C. Ascorbic acid or vitamin C fights bacterial and viral infections which is an effective antioxidant. Several essential minerals exist in pineapples, including manganese, a trace mineral instrumental to the formation of bone. Pineapples minerals also include copper, another trace mineral. It assists in the absorption of iron and regulates blood pressure and heart rate [19].

\section{Banana (Musa spp.)}

Banana pulp contains various antioxidants, e.g., vitamins, carotenoids, and phenolic compounds such as catechin, epicatechin, lignin and tannins, and anthocyanin. Awak pulp contains total phenolic content of about $0.36 \mathrm{mg}$ of gallic acid equivalent/g fresh weight. Pisang mas contain total phenolic content of about $27 \mathrm{mg}$ of gallic acid equivalent/100g fresh weight, the flavonoid content about $13.7 \mathrm{mg}$ catechin equivalents $/ 100 \mathrm{~g}$ fresh weight. The antioxidant activities of the banana fruit were $0.59 \mu \mathrm{mol} \mathrm{Fe}$ (П)/g fresh weight and a $36.8 \% \mathrm{DPPH}$ inhibition [20].

\section{Pomelo (Citrus grandis)}

Pomelo, also known as pummelo, shaddock or Chinese grapefruit, is commonly classified as common (or white) or pigmented (or pink). Pomelo contain total sugar in pink type $(76.45 \mathrm{mg} / \mathrm{mL}$ ) white type $(77.96 \mathrm{mg} / \mathrm{mL})$. Ascorbic acid in pink type $(0.22 \mathrm{mg} / \mathrm{mL})$ white type $(0.39 \mathrm{mg} / \mathrm{mL})$. Citric acid in pink type $(14.15 \mathrm{mg} / \mathrm{mL})$ white type $(0.14 \mathrm{mg} / \mathrm{mL})$. Pomelo contain malic acid in pink type $(0.75 \mathrm{mg} / \mathrm{mL})$ white type $(1.94 \mathrm{mg} / \mathrm{mL})$, succinic acid in pink type $(0.05 \mathrm{mg} / \mathrm{mL})$ and white type $(0.39 \mathrm{mg} / \mathrm{mL})$ [21] 


\section{Methods of fruit vinegar production [7]}

The fruits were used for the production of vinegars via a 2-stage (alcoholic and acetous) fermentation process. The fruits were crushed and mixed with water at a ratio of 1:1 to prepare the juice. After adjustment of the $\mathrm{pH}$ to $4.0-4.5$ and sugar content up to $20-25^{\circ} \mathrm{Brix}$, the juice was pasteurized for $30 \mathrm{~min}$ at $60{ }^{\circ} \mathrm{C}$. Alcoholic fermentation was conducted for $5-7$ days at room temperature under static conditions in plastic vessels containing $3 \mathrm{~L}$ of the juice inoculated with Saccharomyces cerevisiae at a ratio of $0.75 \%(\mathrm{v} / \mathrm{v})$. Preparation of yeast inoculum was carried out by mixing $5 \mathrm{~g}$ of yeast powder with $60 \mathrm{~mL}$ of warm water. At the end of the fermentation process, the obtained wine was separated from the sediment by allowing it to settle in glass bottles, followed by pasteurization for 30 min at $60{ }^{\circ} \mathrm{C}$ and clarification for 45 days at $10{ }^{\circ} \mathrm{C}$. Prior to the acetous fermentation, the alcohol content of the obtained wine was adjusted to $4-10$. Acetous fermentation was performed for 15 days under the aforementioned conditions in glass vessels containing $135 \mathrm{~mL}$ of the wine inoculated with Acetobacter pasteurianus TISTR 521 at a ratio of $10 \%(\mathrm{v} / \mathrm{v})$. Sampling was performed at given time points to collect the 2-stage fermented vinegars by allowing them to settle in microtube and storage at $4{ }^{\circ} \mathrm{C}$ in microtubes before the analyses (Figure 1).

The juice $1 \mathrm{~L}$

(The fruits : water ratio $1: 1$ )

adjust soluble solid content $20-25^{\circ}$ Brix by sugar and adjust $\mathrm{pH} 4.0-4.5$

The juice was pasteurized for $30 \mathrm{~min}$ at $60{ }^{\circ} \mathrm{C}$

$3 \mathrm{~L}$ of the juice

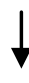

inoculated with $0.75 \%$ inoculum of

Saccharomyces cerevisiae

Alcoholic fermentation was conducted for 4 - 7 days at room temperature

The wine was pasteurized for $30 \mathrm{~min}$ at $60^{\circ} \mathrm{C}$

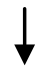

The alcohol content of the wine was adjusted to $4-10 \%$

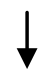

$135 \mathrm{~mL}$ of the wine

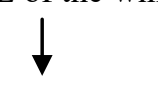

inoculated with $10 \%$ inoculum of Acetobacter pasteurianus

Acetic fermentation was conducted for 15 days at room temperature

Vinegar was pasteurized for $30 \mathrm{~min}$ at $60{ }^{\circ} \mathrm{C}$

Figure 1 Diagram of fruit vinegar production. 
Change of alcohol and acetic acid content using alcoholic and acetous fermentation process of fruits vinegar

A study by [7] reported that after 8 days of alcoholic fermentation, the total soluble solid content from $22{ }^{\circ}$ Brix decreased due to its consumption by yeast. The Namdokmai cultivar has the highest alcohol percentage $(14.82 \pm 0.11 \% \mathrm{v} / \mathrm{v})$. In 15 days of acetous fermentation, the initial concentrations of alcohol content was $7 \% \mathrm{v} / \mathrm{v}$, the final acetic acid was produced from its culivar was $4.88 \% \mathrm{v} / \mathrm{v}$.

A study by [8] reported that the mulberry wine was produced for 7 days, the total soluble solid content begins at $22{ }^{\circ}$ Brix. Finally, its wine has an alcohol percentage $(11.37 \pm 0.03 \mathrm{v} / \mathrm{v})$. In 15 days of acetous fermentation, the initial concentrations of alcohol content were $7 \% \mathrm{v} / \mathrm{v}$, the final acetic acid was produced from its vinegar was $3.96 \% \mathrm{v} / \mathrm{v}$.

Similarly reported by [22] the data showed about the production of the red plum vinegar, start with the alcohol content was $6.49 \pm 0.34 \% \mathrm{v} / \mathrm{v}$. In 15 days of acetous fermentation, the acetic acid was $4.04 \pm$ $0.19 \% \mathrm{v} / \mathrm{v}$ (Tables 3 and $\mathbf{4})$.

Table 3 Percentage of alcohol content in wine.

\begin{tabular}{|c|c|c|c|c|c|c|}
\hline $\begin{array}{c}\text { Raw } \\
\text { material }\end{array}$ & Cultivar & $\begin{array}{l}\text { Detection } \\
\text { method }\end{array}$ & $\begin{array}{l}\text { Initial total } \\
\text { soluble solid }\end{array}$ & $\begin{array}{c}\%(v / v) \\
\text { Alcohol content }\end{array}$ & $\begin{array}{l}\text { Period } \\
\text { (Day) }\end{array}$ & Reference \\
\hline Tamarind & $\begin{array}{l}\text { Si Thong } \\
\text { Pra Kai Thong } \\
\text { Si Chom Phu } \\
\text { Yak Fak Dab }\end{array}$ & GC-FID & 22 & $\begin{array}{l}9.33 \\
8.40 \\
9.34 \\
9.38\end{array}$ & 7 & [5] \\
\hline Cantaloupe & $\begin{array}{l}\text { Aka } \\
\text { Amy } \\
\text { Honeyworld } \\
\text { Kimoji }\end{array}$ & HPLC & 20 & $\begin{array}{l}14.20 \pm 0.59 \\
14.34 \pm 0.44 \\
14.75 \pm 0.55 \\
12.27 \pm 0.84\end{array}$ & 7 & [6] \\
\hline Mango & $\begin{array}{l}\text { Namdokmai } \\
\text { Kalon } \\
\text { Keaw } \\
\text { Chokanan } \\
\text { Mahacharnok }\end{array}$ & HPLC & 22 & $\begin{array}{l}14.82 \pm 0.11 \\
9.14 \pm 1.41 \\
12.01 \pm 0.18 \\
9.31 \pm 0.05 \\
10.56 \pm 0.05\end{array}$ & 8 & [7] \\
\hline Berry & $\begin{array}{l}\text { Mulberry } \\
\text { Cranberry } \\
\text { Raspberry } \\
\text { Blackberry }\end{array}$ & HPLC & 22 & $\begin{array}{l}11.37 \pm 0.03 \\
5.72 \pm 0.08 \\
11.49 \pm 0.04 \\
11.73 \pm 0.01\end{array}$ & 7 & [8] \\
\hline Pineapple & $\begin{array}{l}\text { Homsuwan } \\
\text { Huamui } \\
\text { Puttavia } \\
\text { Tradsrithong }\end{array}$ & GC-FID & 20 & $\begin{array}{l}12.55 \pm 0.61 \\
11.32 \pm 1.83 \\
11.41 \pm 0.68 \\
12.44 \pm 0.68\end{array}$ & 5 & [9] \\
\hline Banana & $\begin{array}{l}\text { Khai Pra Tabong } \\
\text { Nak } \\
\text { Hin } \\
\text { Phama Heak Kuk } \\
\text { Gros Michel }\end{array}$ & HPLC & 18 & $\begin{array}{l}6.66 \pm 0.00 \\
9.54 \pm 0.01 \\
6.92 \pm 0.00 \\
8.28 \pm 0.00 \\
12.04 \pm 0.02\end{array}$ & 3 & [11] \\
\hline Pumelo & $\begin{array}{l}\text { Thong Dee } \\
\text { Takoy } \\
\text { Tubtim Siam }\end{array}$ & GC-FID & 22 & $\begin{array}{l}13.25 \pm 0.45 \\
13.52 \pm 0.21 \\
15.24 \pm 0.50\end{array}$ & 5 & [12] \\
\hline Red plum & Ju-li & HPLC & 24 & $6.49 \pm 0.34$ & 5 & {$[22]$} \\
\hline
\end{tabular}


Table 4 Percentage of acetic acid content in vinegar.

\begin{tabular}{|c|c|c|c|c|c|}
\hline $\begin{array}{c}\text { Raw } \\
\text { material }\end{array}$ & Cultivar & $\begin{array}{l}\text { Detection } \\
\text { method }\end{array}$ & $\begin{array}{l}\text { Initial \%alcohol } \\
\text { content }\end{array}$ & $\begin{array}{c}\%(v / v) \\
\text { Acetic acid content }\end{array}$ & Reference \\
\hline Tamarind & $\begin{array}{l}\text { Si Thong } \\
\text { Pra Kai Thong } \\
\text { Si Chom Phu } \\
\text { Yak Fak Dab }\end{array}$ & $\begin{array}{l}\text { Titratable } \\
\text { acidity }\end{array}$ & 8 & $\begin{array}{l}5.18 \pm 0.63 \\
5.40 \pm 0.16 \\
4.65 \pm 0.71 \\
5.34 \pm 0.06\end{array}$ & [23] \\
\hline Cantaloupe & $\begin{array}{l}\text { Aka } \\
\text { Amy } \\
\text { Honeyworld } \\
\text { Kimoji }\end{array}$ & HPLC & 7 & $\begin{array}{l}6.73 \pm 0.14 \\
7.31 \pm 0.07 \\
6.31 \pm 0.04 \\
6.57 \pm 0.09\end{array}$ & [6] \\
\hline Mango & $\begin{array}{l}\text { Namdokmai } \\
\text { Kalon } \\
\text { Keaw } \\
\text { Chokanan } \\
\text { Mahacharnok }\end{array}$ & HPLC & 7 & $\begin{array}{l}4.88 \pm 0.00 \\
6.96 \pm 0.08 \\
5.47 \pm 0.26 \\
5.72 \pm 0.04 \\
4.90 \pm 0.01\end{array}$ & [7] \\
\hline Berry & $\begin{array}{l}\text { Mulberry } \\
\text { Cranberry } \\
\text { Raspberry } \\
\text { Blackberry }\end{array}$ & HPLC & 7 & $\begin{array}{l}3.96 \pm 0.00 \\
5.01 \pm 0.01 \\
4.74 \pm 0.00 \\
4.72 \pm 0.04\end{array}$ & [8] \\
\hline Pineapple & $\begin{array}{l}\text { Homsuwan } \\
\text { Huamui } \\
\text { Puttavia } \\
\text { Tradsrithong }\end{array}$ & $\begin{array}{l}\text { Titratable } \\
\text { acidity }\end{array}$ & 10 & $\begin{array}{l}2.74 \pm 0.28 \\
2.82 \pm 0.26 \\
2.72 \pm 0.52 \\
3.09 \pm 0.04\end{array}$ & [9] \\
\hline Banana & $\begin{array}{l}\text { Khai Pra Tabong } \\
\text { Nak } \\
\text { Hin } \\
\text { Phama Heak Kuk } \\
\text { Gros Michel }\end{array}$ & HPLC & 6 & $\begin{array}{l}2.27 \pm 0.00 \\
3.49 \pm 0.00 \\
3.23 \pm 0.00 \\
3.24 \pm 0.00 \\
5.13 \pm 0.05\end{array}$ & [11] \\
\hline Pumelo & $\begin{array}{l}\text { Thong Dee } \\
\text { Takoy } \\
\text { Tubtim Siam }\end{array}$ & $\begin{array}{l}\text { Titratable } \\
\text { acidity }\end{array}$ & 4 & $\begin{array}{l}5.46 \pm 0.25 \\
4.83 \pm 0.70 \\
5.16 \pm 0.17\end{array}$ & [12] \\
\hline Red plum & Ju-li & HPLC & 6.49 & $4.04 \pm 0.19$ & [22] \\
\hline
\end{tabular}

\section{Bioactive compounds}

The bioactive compounds in vinegars consist of organic acids, polyphenols, melanoidins, and tetramethylparazine. Bioactive compounds can act as antioxidants, enzyme inhibitors, and inhibitors of gene expression.

\section{Acetic acids}

Acetic acids in vinegar come from fermentative production. Acetic acid was the main organic acid in vinegars, which occurred during the step of alcohol and acetous fermentation. Acetic acid can penetrate the cell membrane of microorganisms and cause bacterial cell death which was the most effective organic acid against Escherichia coli 0157:H7 [2,24]. 


\section{Polyphenols}

The phenolic compound in vinegar exhibit a high antioxidant activity which is capable of reducing oxidative stress in the body, blood pressure control, prevention of cardiovascular diseases [2]. Several studies that the raw materials of fruit vinegars contain polyphenols. It is important to determine the contents of polyphenols, as they play an important role in antioxidant activity. It is worth mentioning that [7] reported that mango vinegar which was produced from Mahacharnok cultivar had the highest antioxidant activity is showed in Table $5(91.00 \pm 2.37 \%)$. In a previous study, [25] founded the volatile compositions in mango vinegar which had antioxidant activity, such as Furaneol, Methionol, and Acetoin. The pineapple vinegar produced from Homsuwan cultivar had the highest total phenolic content (332.34 $\pm 4.87 \mathrm{mg} / \mathrm{mL}$ ) [9]. According to [26] revealed that L-lysine, mullein, and gallic acid were significantly more concentrated in the pineapple vinegar.

Table 5 Antioxidant activity and total phenolic content in vinegar

\begin{tabular}{|c|c|c|c|c|}
\hline Raw material & Cultivar & \%Inhibition & TPC (Mg/L) & Reference \\
\hline Tamarind & $\begin{array}{l}\text { Si Thong } \\
\text { Pra Kai Thong } \\
\text { Si Chom Phu } \\
\text { Yak Fak Dab }\end{array}$ & $\begin{array}{l}32.57 \pm 0.41 \\
11.86 \pm 0.11 \\
20.47 \pm 0.64 \\
47.47 \pm 0.25\end{array}$ & n.d. & {$[23]$} \\
\hline Cantaloupe & $\begin{array}{l}\text { Aka } \\
\text { Amy } \\
\text { Honeyworld } \\
\text { Kimoji }\end{array}$ & $\begin{array}{c}53.78 \pm 0.75 \\
44.47 \pm 1.10 \\
21.26 \pm 4.87 \\
9.00 \pm 0.30\end{array}$ & n.d. & [6] \\
\hline Mango & $\begin{array}{l}\text { Namdokmai } \\
\text { Kalon } \\
\text { Keaw } \\
\text { Chokanan } \\
\text { Mahacharnok }\end{array}$ & $\begin{array}{l}88.30 \pm 5.32 \\
68.51 \pm 2.66 \\
65.73 \pm 3.09 \\
86.37 \pm 4.60 \\
91.00 \pm 2.37\end{array}$ & $\begin{array}{l}71.46 \pm 0.19 \\
82.47 \pm 0.29 \\
65.72 \pm 2.58 \\
117.81 \pm 2.48 \\
83.08 \pm 0.57\end{array}$ & [7] \\
\hline Berry & $\begin{array}{l}\text { Mulberry } \\
\text { Cranberry } \\
\text { Raspberry } \\
\text { Blackberry }\end{array}$ & $\begin{array}{l}25.25 \pm 2.76 \\
30.89 \pm 7.46 \\
74.43 \pm 0.74 \\
72.62 \pm 4.72\end{array}$ & $\begin{array}{l}190.11 \pm 22.05 \\
250.02 \pm 24.19 \\
181.37 \pm 13.51 \\
167.50 \pm 2.20\end{array}$ & [8] \\
\hline Pineapple & $\begin{array}{l}\text { Homsuwan } \\
\text { Huamui } \\
\text { Puttavia } \\
\text { Tradsrithong }\end{array}$ & $\begin{array}{l}67.54 \pm 0.74 \\
84.62 \pm 1.74 \\
89.82 \pm 0.83 \\
78.60 \pm 0.33\end{array}$ & $\begin{array}{l}332.34 \pm 4.87 \\
172.34 \pm 0.29 \\
140.24 \pm 0.00 \\
128.96 \pm 0.10\end{array}$ & [9] \\
\hline Banana & $\begin{array}{l}\text { Khai Pra Tabong } \\
\text { Nak } \\
\text { Hin } \\
\text { Phama Heak Kuk } \\
\text { Gros Michel }\end{array}$ & $\begin{array}{c}47.44 \pm 5.03 \\
68.04 \pm 1.49 \\
69.30 \pm 8.09 \\
80.59 \pm 2.30 \\
73.2 \pm 0.11\end{array}$ & $\begin{array}{l}243.98 \pm 3.35 \\
102.23 \pm 0.69 \\
198.26 \pm 1.61 \\
115.92 \pm 9.40 \\
68.01 \pm 0.21\end{array}$ & [11] \\
\hline Pumelo & $\begin{array}{l}\text { Thong Dee } \\
\text { Takoy } \\
\text { Tubtim Siam }\end{array}$ & $\begin{array}{l}57.75 \pm 3.75 \\
33.65 \pm 4.04 \\
55.31 \pm 0.01\end{array}$ & n.d. & {$[12]$} \\
\hline
\end{tabular}

n.d. $=$ not detected 


\section{Health benefits of vinegar}

According to [24], bioactive compounds affect physiological or cellular activities, resulting in beneficial health effects. Bioactive compounds are claimed to have the ability to modify the risk of disease rather than prevent diseases. In the previous studies [27], tomato vinegar has powerful antivisceral obesity properties in HFD-induced obese rats. The intra-abdominal deposition of visceral adipose tissue is known as a general type of obesity that is associated with conditions such as type 2 diabetes mellitus, hyperlipidemia, hypertension, and coronary heart disease. They found that consuming tomato vinegar regularly can reduce the total visceral fat and the epididymal adipocyte size. According to [28] study examined the effects of vinegar on markers of type 2 diabetes in at-risk adults. The participants $(n=$ 14) were ingested by $750 \mathrm{mg}$ acetic acid as a vinegar drink or a control pill (40 mg acetic acid) twice daily at mealtime. Blood glucose (fasting and $2 \mathrm{~h}$ postprandial) was recorded daily. Fasting blood collected at weeks 0 and 12 was analyzed for insulin and glycated hemoglobin. The average change in fasting glucose was reduced in the vinegar group versus control group $(0.91 \pm 0.27$ versus $0.26 \pm 0.17$ $\mathrm{mmol} / \mathrm{l})(\mathrm{p}=0.05)$. Ok et al. [29] have reported that supplementation of acetic acid and pomegranate vinegar (PV) contributed to lowering both plasma and hepatic triglyceride levels Interestingly, in their study the effectiveness of PV in reducing plasma triglyceride was favored more at a low dose when compared to a high dose. This could be due to various properties of diverse chemical compounds present in PV. Several studies have showed vinegar has a potential to ameliorate obesity, diabetes, cardiovascular disorders, cancer and microbial infections. Daily intake of a drink containing $15 \mathrm{~mL}$ vinegar (750 mg of acetic acid) was reported to improve lifestyle-related diseases, such as hypertension, hyperlipidemia, and obesity [30]

\section{Conclusions}

Vinegar is a well-known fermented food produced by different raw materials. This paper has summarized the chemical fermentation process properties, bioactive compounds, and health benefits of fruit vinegars in pilot-scale. Thailand has a lot of fruits that can produce vinegars, including Mango, Mulberry, Pineapple, Banana, and Red Plum. The findings of this study are expected to shed light on the effort for improving people's wellness through vinegar consumption.

\section{References}

[1] L Solieri and P Giudici. Vinegars of the World. Springer Milan, Milano, Italia, 2009, p. 1-16.

[2] T Xia, B Zhang, W Duan, J Zhang and M Wang. Nutrients and bioactive components from vinegar: A fermented and functional food. J. Funct. Foods. 2020; 64, 1-14.

[3] I Ozturk, O Caliskan, F Tornuk, N Ozcan, H Yalcin, M Baslar and O Sagdic. Antioxidant, antimicrobial, mineral, volatile, physicochemical and microbiological characteristics of traditional home-made Turkish vinegars. LWT - Food Sci. Tech. 2015; 63, 144-51.

[4] M Ozen, N Ozdemir, BE Filiz, NH Budak and T Kok-Tas. Sour cherry (Prunus cerasus L.) vinegars produced from fresh fruit or juice concentrate: Bioactive compounds, volatile aroma compounds and antioxidant capacities. Food Chem. 2020; 309, 125664.

[5] W Boonsupa, K Malaporn, J Butlee, W Simma, P Butrobon, P Ponmueng, L Pathathanta and W Hompan. Study of chemical properties, sensory test and antioxidant activity of Tamarind wine. In: Proceedings of the Sakon Nakhon Rajabhat University International Conference, Sakon Nakhon, Thailand. 2015, p. ST38-ST43.

[6] W Boonsupa, K Ponkun, J Kaewket, T Jandondang, K Nuntalit and K Buapat. Chemical property, antioxidant activity and sensory evaluation of fermented vinegar from 4 cantaloupe cultivars. J. Sci. Tech. Ubon Ratchathani Univ. 2017; 19, 187-96.

[7] W Boonsupa. Chemical properties, antioxidant activities and sensory evaluation of mango vinegar. Int. J. Agr. Tech. 2019; 15, 229-40.

[8] W Boonsupa. Chemical properties, antioxidant activities and sensory evaluation of berry vinegar. Walailak J. Sci. Tech. 2019; 16, 887-96. 
[9] W Boonsupa, K Thongdonpriang, T Pookchalee, P Phupadong, N Khodtip and N Sansom. Chemical property, antioxidant activity and sensory evaluation of fermented vinegar from 4 pineapple cultivars. UTK Res. J. 2017; 11, 26-38.

[10] W Boonsupa, W Pimda, K Sreeninta, C Yodon, N Samorthong, B Bou-on and P Hemwiphat. Development of fermented Banana vinegar: Chemical characterization and antioxidant activity. $J$. Food Health Bioenviron. Sci. 2019; 12, 21-7.

[11] W Boonsupa, S Chumchuere and M Chaovarat. Physicochemical properties and antioxidant activity of banana vinegar produced using one-stage and two-stage fermentation. Agr. Nat. Resour. 2019; 53, 298-305.

[12] W Boonsupa, K Lamai, C Uthihong, S Teppalun, O Wanghin, P Srikaensai, R Suensiri and A Paitap. Chemical properties, antioxidant activity and sensory evaluation of fermented vinegar from 3 cultivars of pummelo. VRU Res. Dev. J. Sci. Tech. 2019; 14, 86-94.

[13] S Bhat, R Akhtar and $\mathrm{T}$ Amin. An overview on the biological production of vinegar. Inter. J. Ferment. Foods. 2014; 3:139-55.

[14] P Raspor and D Goranovic. Biotechnological applications of acetic acid bacteria. Crit. Rev. Biotechnol. 2008; 28, 101-24.

[15] YS Rao and KM Mathew. Tamarind. Handbook of Herbs and Spices. Vol I. Woodhead Publishing Limited, New Dehli, India, 2012, p. 512-33.

[16] P Perkins-Veazie, JC Beaulieu and M Siddiq. Watermelon in: Cantaloupe and Honeydew. Tropical and Subtropical Fruits: Postharvest Physiology, Processing and Packaging. John Wiley \& Sons, New Jersey, USA, 2012, p. 549-68.

[17] H Rymbai, M Srivastav, RR Sharm, CR Patel and AK Singh. Bio-active compounds in mango (Mangifera indica L.) and their roles in human health and plant defence: A review. J. Horticultural Sci. Biotechnol. 2015; 88, 367-79.

[18] L Wang, X Sun, F Li, D Yu, X Liu, W Huang and J Zhan. Dynamic changes in phenolic compounds, colour and antioxidant activity of mulberry wine during alcoholic fermentation. $J$. Funct. Foods 2015; 18, 254-6.

[19] V Chaudhary, V Kumar, S Vaishali, K Sing, R Kumar and V Kumar. Pineapple (Ananas cosmosus) product processing: A review. J. Pharmacognosy. Phytochem. 2019; 8, 4642-52.

[20] A Pereira and M Maraschin. Banana (Musa spp) from peel to pulp: Ethnopharmacology, source of bioactive compounds and its relevance for human health. J. Ethnopharmacol. 2015; 160, 149-63.

[21] MW Cheong, SQ Liu, W Zhou, P Curran and B Yu. Chemical composition and sensory profile of pomelo (Citrus grandis (L.) Osbeck) juice. Food Chem. 2012; 135, 2505-13.

[22] W Boonsupa and K Kerdchan. Development of fermented prunus vinegar: Chemical characterization and antioxidant activity. Current Appl. Sci. Technol. 2021; 21, 75-84.

[23] W Boonsupa, J Yadsom, C Kumkodsoon, P Papeso and P Sattawaho. Chemical quality, antioxidant activity and sensory evaluation of fermented vinegar from 4 tamarind cultivars (Srethong, phakaythong, srechompoo, and yakfakdab). RMUT J. Sci. Tech. 2015; 9, 224-33.

[24] CW Ho, AM Lazim, S Fazry, UKHH Zaki and SJ Lim. Varieties, production, composition and health benefits of vinegars: A review. Food Chem. 2017; 221, 1621-30.

[25] E Coelho, Z Genisheva, JM Oliveira, JA Teixeira and L Domingues. Vinegar production from fruit concentrates: effect on volatile composition and antioxidant activity. J. Food Sci. Technol. 2017; 54, 4112-22.

[26] A Roda, L Lucini , F Torchio, R Dordoni, DM De Faveri and M Lambri. Metabolite profiling and volatiles of pineapple wine and vinegar obtained from pineapple waste. Food Chem. 2017; 229, 734-42.

[27] JY Lee, HD Cho, JH Jeong, MK Lee, YK Jeong, KH Shim and KI Seo. New vinegar produced by tomato suppresses adipocyte differentiation and fat accumulation in 3T3-L1cells and obese rat model. Food Chem. 2013; 141, 3241-9.

[28] CS Johnston, S Quagliano and S White. Vinegar ingestion at mealtime reduced fasting blood glucose concentrations in healthy adults at risk for type 2 diabetes. J. Funct. Foods 2013; 5, 200711 . 
[29] E Ok, GM Do, Y Lim, JE Park, YJ Park and O Kwon. Pomegranate vinegar attenuates adiposity in obese rats through coordinated control of AMPK signaling in the liver and adipose tissue. Lipids Health Dis. 2013, 12.

[30] A Samad, A Azlan and A Ismail. Therapeutic effects of vinegar: A review. Curr. Opin. Food Sci. 2016, 8, 56-61. 